19. van Hoof, F., and Hers, H. G.: The abnormalities of lysosomal enzymes in mucopolysaccharidoses. Europ. J. Biochem., 7: 34 (1968).

20. HTI Corp., Buffalo, N. Y

21. MISCO Scientific, Berkeley, Calif

22. Gift of Dr. Elizabeth F. Neufeld, National Institutes of Health, Bethesda Maryland; prepared by Dr. Bernard Weissmann under Grant no NIHNIAMDD 73-2205

23. Sigma Chemical Co., St. Louis, Mo

24. Gilford Instrument Laboratories, Inc., Oberlin. Ohio.

25. Coulter Electronics, Inc., Hialeah, Fla.
26. Ames Company. Division Miles Laboratories, Inc., Elkhart, Ind

27. Informed consent was obtained for all subjects in this study.

28. This study was supported by grants from the Riley Memorial Association (Project no. 74-9) and the National Institute of Arthritis, Metabolism, and Digestive Diseases. United States Public Health Service, no. IF22 AM0338801 .

29. Requests for reprints should be addressed to: Dr. R. Wappner, The James Whitcomb Riley Hospital for Children, Rm. A-36, 1100 W. Michigan St. Indianapolis, Ind. 46202 (USA)

30. Accepted for publication January 14, 1976

\title{
The Chronically Reserpinized Rat as a Possible Animal Model for Cystic Fibrosis. IV. The Protein Composition of Pulmonary Lavage Fluid
}

\author{
FREDERICK E. THOMPSON, DAVID O. QUISSELL, CHARLES H. WILLIAMS, 20 \\ AND J. R. MARTINEZ \\ Departments of Medicine, Biochemistry, and Child Health, University of Missouri and Harry S. Truman Memorial \\ Veterans Hospital, Columbia, Missouri, USA
}

\section{Extract}

Lung lavage samples obtained from patients with cystic fibrosis (CF) had significantly higher levels of total protein per $\mathrm{ml}$ lavage fluid $(0.49 v s .0 .30 \mathrm{mg} / \mathrm{ml})$. A significant increase in the absolute and relative amounts of a low molecular weight glycoprotein $(15,000 \mathrm{~mol} w \mathrm{wt})$ was noted in lavage specimens from $\mathrm{CF}$ patients. Reserpine-treated rats also showed a significant increase in the total protein recovered in the lung lavage fluid with a $233 \%$ increase in the absolute and relative amounts of a low molecular weight glycoprotein $(15,000 \mathrm{~mol} \mathrm{wt})$. Thus, reserpine induces changes in the secretions of the lung of the rat which are similar to those observed in samples obtained from the lungs of CF patients.

\section{Speculation}

The administration of reserpine to rats, which has been previously shown to produce morphologic changes in various exocrine tissues and abnormaiities in the composition of submaxiilary saliva similar to those reported for $\mathrm{CF}$ patients, should result in changes in the composition of other exocrine gland secretions.

Cystic fibrosis is a hereditary disorder in which there is a postulated defect in regulation of exocrine gland secretion. Typically there is a generalized accumulation of a highly viscous mucus in the ducts and surfaces of exocrine glands (4-6). Chronic bronchiolar obstruction as a result of mucous plugging and subsequent pulmonary infection are the most frequent cause of death among cystic fibrotics. The distended appearance of mucous glands of the tracheobronchial tree indicates a hypersecretory state (1).

The exact mechanism by which the genetic error is expressed remains unknown. The possible role of disturbances in the neurohumoral regulation of exocrine glands was suggested several years ago (2) and later, it was shown that chronic administration of a $\beta$-adrenergic agent (isoproterenol) to rats induced suggestive changes in the salivary glands (11). More recently, morphologic and secretory changes in the rat submaxillary gland have been induced by chronic administration of reserpine $(9,12,13)$. In this model, submaxillary saliva showed increased concentrations of protein, carbohydrate, and calcium $(10,12,13)$.

These abnormalities in the composition of submaxillary saliva from the reserpine-treated animals, together with evidence that the drug treatment also induces morphologic changes in other exocrine tissues (9), directed our interest to the protein composition of pulmonary secretions. In this investigation we have compared, therefore, the protein composition of lung lavage samples from patients with cystic fibrosis and from reserpine-treated rats. We expected to find an abnormal protein specific for cystic fibrosis, but, after a few experiments, it became evident that cystic fibrotic lavage fluid contained the same proteins found in other nonsecretory pulmonary diseases, but that they were present in different proportions. Likewise, lavage fluid from reserpine-treated rats had qualitatively the same protein electrophoretic pattern as control animals, but the quantity of one low molecular weight glycoprotein was markedly increased. Significantly, we found that a similar glycoprotein was also increased in the lavage material from cystic fibrotic patients

\section{METHODS}

\section{RESERPINE-TREATED RATS}

This section of the study was performed on five groups of 4 adult sibling male rats for a total of 10 controls and 10 treated animals. The latter were treated daily for 7 days with intraperitoneal injections of $0.5 \mathrm{mg} / \mathrm{kg}$ reserpine $(12,13)$. On the 8 th day, both 
Table 1. Types of diseases of patients in study ${ }^{1}$

\begin{tabular}{|c|c|c|c|c|c|}
\hline Patient & Age, $y r$ & Wt, lbs & $\begin{array}{l}\text { Volume of } \\
\text { lavage, liters }\end{array}$ & $\begin{array}{l}\text { Type of } \\
\text { disease }\end{array}$ & $\begin{array}{c}\text { Severity of } \\
\text { disease }\end{array}$ \\
\hline$l$ & 27 & 111 & 27 & $\mathrm{CF}$ & Moderate \\
\hline 2 & 19 & 134 & 21 & $\mathrm{CF}$ & Moderate \\
\hline 3 & 21 & 118 & 19.5 & $\mathrm{CF}$ & Moderate \\
\hline 4 & 9 & 58 & 15 & PAP & Mild-moderate \\
\hline
\end{tabular}

${ }^{\prime} \mathrm{CF}$ : cystic fibrosis; PAP: pulmonary alveolar proteinosis. Specimen samples provided by Dr. A. Spock. The other non-CF patients were $50,6 \mathrm{I}, 8$, and 58 years old.

control and reserpine-treated rats were anesthetized with $8 \mathrm{mg} / 100$ $\mathrm{g}$ body wt of sodium pentobarbital and the trachea exposed by a midline neck incision. The trachea was intubated with a small caliber plastic tube and twice lavaged with $0.06 \mathrm{ml} / \mathrm{g}$ body wt saline. The lavage samples were kept on ice until analyzed by the methods listed below. After lavaging the lungs were removed, blotted dry, and weighed to determine whether the lung weight to body weight ratio was similar for both groups.

\section{HUMAN SUBJECTS}

Four cystic fibrosis patients and four patients with alveolar filling diseases (lipoid pneumonia and pulmonary alveolar proteinosis) were lavaged by the whole lung (Clarlen's tube) method of Ramirez (14) (Table 1). Samples were kept on ice until processed. The cystic fibrosis and pulmonary alveolar proteinosis lung lavage specimens were provided by Dr. Spock of Duke University.

The samples obtained from Dr. Spock were initially centrifuged and then frozen. They were thawed, an aliquot prepared, refrozen, and shipped frozen in Dry Ice from Raleigh, North Carolina to Columbia, Missouri by air. The volume of lavage was not proportional to body weight because of variations in the severity of the disease, and lavaging was primarily for therapeutic purposes

The other non-CF patients were $50,61,8$, and 58 years old.

\section{ANALYSIS OF LAVAGE SAMPLES}

The saline lavage fluid samples collected from rats and patients were centrifuged within an hour of collection at 3,000 rpm for 15 min to separate cells, cellular debris, and insoluble material from the soluble compounds in the supernatant. A sample of the supernatant was assayed for total protein concentration by the Lowry protein assays, using the Folin-Ciocalteau reagent and copper tartrate (10). The small volume of rat lavages prevented further measurements of lipids and carbohydrates. The remaining supernatant was extensively dialysed against several changes of distilled water at $4^{\circ}$ (the molecular weight cut-off of the dialysis tubing was 3,000 ). This dialysate was lyophilized to a dry powder and twice extracted with $n$-butanol and acetone to remove protein bound lipids. The recovered lipid-free protein material was dissolved to a concentration of $25 \mathrm{mg} / \mathrm{ml}$ in a solution containing $1 \%$ sodium dodecyl sulfate (SDS), $0.1 \%$ dithiothreitol, and a Tris-glycine buffer at $\mathrm{pH}$ 9.0. Standard proteins of known molecular weight and normal rat and human serum were prepared in the same medium.

The electrophoretic procedure of Fairbanks et al. (8) was used for separation, staining, and molecular weight estimation of protein and glycoprotein components of each lavage sample. The proteins and glycoproteins were separated on $1 \%$ SDS, $0.1 \%$ dithiothreitol, $7.5 \%$ polyacrylamide $\mathrm{pH} 9.0$ disc gels.

The number of protein monomers, their molecular weight, and relative concentration were calculated. Molecular weights were estimated by comparison of the relative mobilities of unknown proteins with a series of known protein standards (15) (see Fig. 1). The carbohydrate moiety of glycoproteins were detected with a periodic acid-Schiff staining technique applied to polyacrylamide gels. Relative concentrations of each protein monomer were calculated from densitometric scans of gels as percent of total

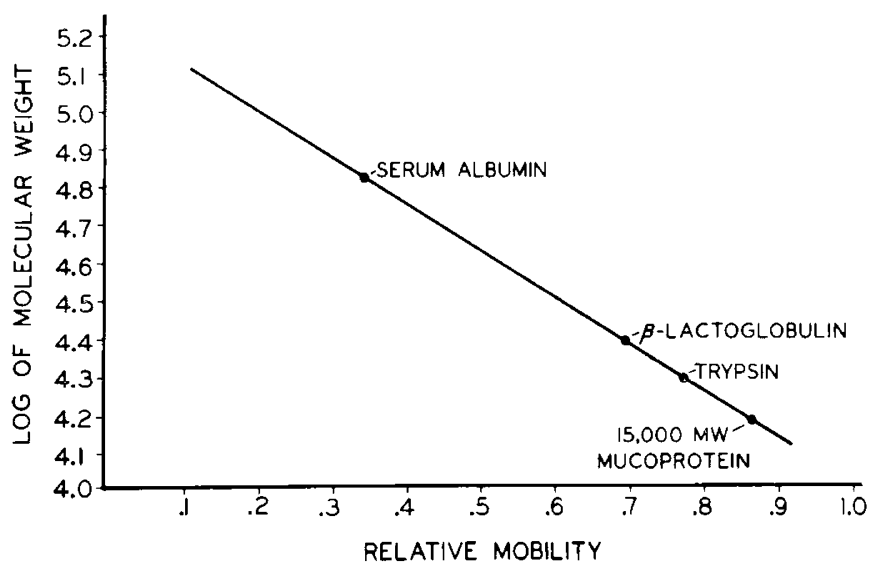

Fig. I. Relative mobility vs. log of molecular weight curve for determination of molecular weight of unknown protein on sodium dodecyl sulfate disc gels.

Table 2. Protein content of lavage specimens

\begin{tabular}{llc}
\hline & $\begin{array}{c}\text { Total protein } \\
\text { in lavage, } \mathrm{mg} / \mathrm{ml}\end{array}$ & $\begin{array}{c}\text { Total protein } \\
\text { in lavage, } \\
\mu \mathrm{g} / \mathrm{g} \text { body } \mathrm{wt}\end{array}$ \\
\hline $\begin{array}{l}\text { Cystic fibrosis } \\
\text { Alveolar filling diseases }\end{array}$ & $0.49( \pm 0.33)$ & $67( \pm 32)$ \\
Reserpine-treated rats & $0.30( \pm 0.27)$ & $15( \pm 7)$ \\
Control rats & $0.353( \pm 0.034)$ & $33.4( \pm 2.36)$ \\
& $0.250( \pm 0.041)$ & $18.4( \pm 4.09)$
\end{tabular}

protein (7). The gels were stained with Coomassie blue and photoscanned on a Gilford 2400-S spectrophotometer equipped with a linear transport attachment and recorder.

\section{RESULTS}

TOTAL PROTEIN ASSAY

The total protein concentration in lavage material from reserpine-treated rats averaged $80 \%$ greater than in lavage fluid from control animals. The mean protein level in the treated animals was $33.4 \mu \mathrm{g} / \mathrm{g}$ body wt and in the control animals, $18.4 \mu \mathrm{g} / \mathrm{g}$ body weight. The wet lung weight/body weight ratio was constant for both groups, even though the sibling control rats (mean body wt of $246 \mathrm{~g}$ ) outweighed the treated animals (mean body wt of $153 \mathrm{~g}$ ) (see Table 2).

Total protein levels in lavage fluid from CF patients were consistently elevated over those observed in the alveolar filling disease group. The cystic fibrotic protein level averaged 0.49 $\mathrm{mg} / \mathrm{ml} \pm 0.33$, and the noncystic fibrotic protein concentration was $0.30 \mathrm{mg} / \mathrm{ml} \pm 0.27$ (see Table 2).

\section{ELECTROPHORETIC PATTERNS}

Protein electrophoretic patterns of lavage fluid from reserpinetreated rats failed to show any consistent inclusion or exclusion of 


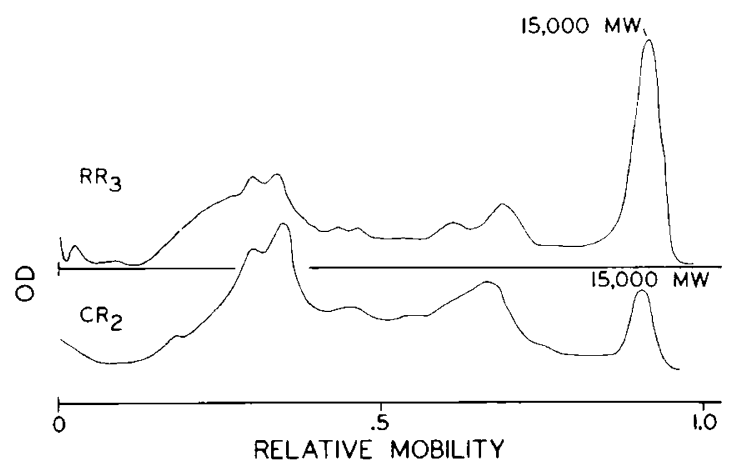

Fig. 2. Densitometric scans of sodium dodecyl sulfate disc gels stained with Coomassie blue. $R R_{3}$ : reserpine-treated rat sample; $C R_{2}$ : control rat sample.

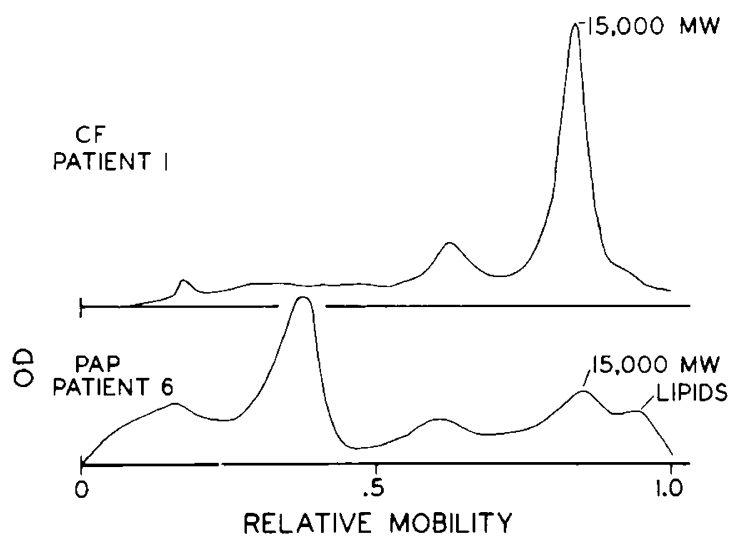

Fig. 3. Densitometric scans of sodium dodecyl sulfate disc stained with Coomassie blue. Cystic fibrosis $(C F)$ patient $l$ is on the upper line pulmonary alveolar proteinosis $(P A P)$ patient 6 on the lower line.

protein monomers when compared to the control animal group (see Fig. 3). The patient group protein scans were more variable in content, with occasional peak splitting, but showed no statistically significant protein monomer specific for either group (see Fig. 3). All patient and rat lavages consistently contained protein monomers of $15,000,31,000$, and 69,000 molecular weights. The other proteins were to some degree variable in their occurrence.

It should be pointed out here that many of the protein monomers found in lavage fluid had molecular weights comparable to serum proteins (albumin, immunoglobulin G). Other proteins in lavage fluid had no counterpart in serum; most notable was a $15,000 \mathrm{~mol} w \mathrm{w}$ glycoprotein. In both the CF patient and the reserpine-treated rat there was a significant increase in a 15,000 mol wt glycoprotein (Figs. 2 and 3) which did not occur either in patients with other types of pulmonary disease or in the control rats.

\section{DISCUSSION}

The accumulation in the lung of a viscous, relatively insoluble secretory fluid in cystic fibrosis patients plays a dominant role in the progressive development of serious pulmonary dysfunction and disease. Palliative therapy with total lung lavage has been temporarily beneficial in some cases (14). We have previously observed the accumulation of a $15,000 \mathrm{~mol}$ wt glycoprotein in the lung of a 23-year-old female patient who may have a late onset type of cystic fibrosis (16).

We have characterized the proteins that are present in lung lavage fluid of cystic fibrosis and other alveolar filling diseases on SDS disc gels. The lavage fluids from CF patients had a higher concentration of protein $(0.49 \mathrm{mg} / \mathrm{ml} \pm 0.33)$ when compared with the non-cystic fibrosis patients $(0.30 \mathrm{mg} / \mathrm{ml} \pm 0.27)$. The same was true of the lavage fluid from reserpine-treated rats when compared with that of control rats. The former had $80 \%$ more protein per $\mathrm{g}$ body wt.

The protein electrophoretic pattern of the material from both the reserpine-treated rat and from cystic fibrosis patients did demonstrate a definite shift in the percentage of distribution of a protein monomer that was not seen in the control groups. This was an increase in the relative and absolute amount of a $15,000 \mathrm{~mol} \mathrm{wt}$ glycoprotein. This $15,000 \mathrm{~mol}$ wt glycoprotein comprised a mean $14 \% \pm 2.5 \%$ of the total protein in lavage fluid from treated rats. This is a $233 \%$ increase over the mean in control animals of $6 \% \pm$ $1.2 \%$ of total protein. A similar glycoprotein was found to be increased in lavage fluid of the cystic fibrosis group when compared with the lipoid pneumonia and alveolar proteinosis group. In the cystic fibrosis group this protein comprised $46 \% \pm$ $14 \%$ of the total protein, whereas in the non-cystic group this protein represented only $5.75 \% \pm 6.4 \%$ of total protein.

An increase in the relative and absolute amount of a $15,000 \mathrm{~mol}$ wt glycoprotein in the lavage fluid of cystic fibrosis patients suggests that this protein may be accumulating in the airways because of a hypersecretion or decreased catabolism. The observation that a similar banding pattern on the disc ge!s of lavage fluid from reserpine-treated rats shows a $233 \%$ increase of a $15,000 \mathrm{~mol}$ wt glycoprotein indicates that reserpine affects the lung of the rat and causes a shift in protein composition which is very similar to that observed in the cystic fibrosis patients.

\section{SUMMARY}

The accumulation in the lung of a viscous, relatively insoluble secretory fluid in cystic fibrosis patients plays a dominant role in the progressive development of serious pulmonary dysfunction and disease. Our results show that a $15,000 \mathrm{~mol}$ wt glycoprotein is one of the major components accumulating in the lungs of cystic fibrosis patients.

A similar change in glycoprotein composition of lung lavage fluid was also observed in reserpine-treated rats.

\section{REFERENCES AND NOTES}

1. Andersen, D. H.: Pathology of cystic fibrosis. Ann. N.Y. Acad. Sci., 93: 500 (1962).

2. Barbero, G. J., and Chernick, W. J.: The role of the autonomic nervous system in cystic fibrosis. In: P. A. DiSant' Agnese: Research on Pathogenesis of Cystic Fibrosis, p. 208 (Bethesda, Md., 1966)

3. Chaikrin, L. W., Baker, A. P., Christain, P., and Wardell, J. R., Jr.: Effect of cholinergic stimulation on the release of macromolecules by canine trachea in vitro. Amer. Rev. Resp. Dis., 108: 69 (1973).

4. Di Sant Agnese, P. A., and Talamo, R. C.: Pathogenesis and physiopathology of cystic fibrosis of the pancreas. New Engl. J. Med., 277: 1287 (1967).

5. Di Sant Agnese, P. A., and I alamo, R. C.: Pathogenesis and physiopathology of cystic fibrosis of the pancreas. New Engl. J. Med., 277: 1343 (1967)

6. Di Sant' Agnese, P. A., and Talamo, R. C.: Pathogenesis and physiopathology of cystic fibrosis of the pancreas. New Engl. J. Med., 277: 1399 (1967).

7. Fenner, C.. Traut, R. R. Mason, D. T., and Wikman-Coffelt, J. Quantification of Coomassie blue stained proteins in polyacrylamide gels based on analysis of eluted dye. Anal. Biochem., 63: 595 (1975).

8. Fairbanks, G., Steck, T. L., and Wallach, D.: Electrophoretic analysis of the major polypeptides of the human erythrocyte membrane. Biol. Chem., 10:2606 (1971).

9. Immken, L., Martinez, J. R.. Hess, R.. and Barbero, G. J.: The chronically reserpinized rat as a possible model for CF. III. Histochemistry of exocrine glands. CF Club Abstracts, XVI Annual Meeting, p. 9 (1975).

10. Lowry, O. H., Rosebrough, N. J., Farr, A. L., and Randall, R. J.: Protein measurement with the Folin phenol reagent. J. Biol, Chem., 193: 265 (1951).

11. Mangos, J. A., McSherry, N. R.. Benke, P. J., and Spock, A.: Studies on the pathogenesis of cystic fibrosis: The isoproterenol treated rat as an experimental model. In: Proceedings of the 5th International Cystic Fibrosis Conference, p. 25 (Cystic Fibrosis Research Trust, London, 1969).

12. Martinez, J. R., Adelstein, E., Quissell, D. O., and Barbero, G. J.: The chronically reserpinized rat as a possible model for cystic fibrosis. I. Submaxillary gland morphology and ultrast ructure. Pediat. Res., 9: 463 (1975).

13. Martinez, J. R., Adshead, P. C., Quissell, D. O., and Barbero, G. J.: The chronically reserpinized rat as a possible model for cystic fibrosis. II Composition and cilioinhibitory effects of submaxillary saliva. Pediat. Res., 9 . 470 (1975).

14. Ramirez, R. J.: Bronchopulmonary lavage: New techniques and observations. Dis. Chest, 50: 581 (1966).

15. Weber, K., and Osborn, M.: The reliability of molecular weight determinations 
by dodecylsulfate-polyacrylamide gel electrophoresis. J. Biol. Chem., 244: 4406 (1969).

16. Williams, C. H. Thompson, F. E.. Thurston, R. J., and Kilburn, K. H.: Glycoprotein accumulation in diffuse lung disease. Clin. Res., 23: 533A (1975).

17. Reserpine was obtained from the Vitarine Company, New York.

18. We thank Dr. A Spock of Duke University for the lavage samples from cystic fibrotic patients, Mrs. Velma Fischbeck for typing the manuscript, and Wayne

Copyright @ 1976 International Pediatric Research Foundation, Inc.
Meyer for the illustrations.

19. This research was supported in part by a grant from the Cystic Fibrosis Foundation. Dr. Martinez has a Research Scholar Award from the Cystic Fibrosis Foundation.

20. Requests for reprints should be addressed to: C. H. Williams, Ph.D., Departmen of Medicine, Harry S. Truman Memorial Veterans Hospital, Columbia, Mo. 65201 (USA).

21. Accepted for publication January 14, 1976

Printed in U.S.A. 